\title{
SOCIAL BIOLOGY AND POPULATION IMPROVEMENT
}

\begin{abstract}
$I^{N}$ response to a request from Science Service, of Washington, D.C., for a reply to the question "How could the world's population be improved most effectively genetically ?", addressed to a number of scientific workers, the subjoined statement was prepared, and signed by those whose names appear at the end.
\end{abstract}

The question "How could the world's population be improved most effectively genetically ?" raises far broader problems than the purely biological ones, problems which the biologist unavoidably encounters as soon as ho tries to get the principles of his own special field put into practice. For the effective genetic improvement of mankind is dependent upon major changes in social conditions, and correlative changes in human attitudes. In the first place, there can be no valid basis for estimating and comparing the intrinsic worth of different individuals, without economic and social conditions which provide approximately equal opportunities for all members of society instead of stratifying them from birth into classes with widely different privileges.

The second major hindranco to genetic improvement lies in the economic and political conditions which foster antagonism between different peoples, nations and 'races'. The removal of race prejudices and of the unscientific doctrine that good or bad genes are the monopoly of particular peoples or of persons with features of a given kind will not be possible, however, before the conditions which make for war and economic exploitation have been eliminated. This requires some effective sort of federation of the whole world, based on the common interests of all its peoples.

Thirdly, it cannot bo expected that tho raising of children will be influenced actively by considerations of the worth of future generations unless parents in general have a very considerable economic security and unless they are extended such adequate economic, medical, educational and other aids in the bearing and rearing of each additional child that the having of more children does not overburden either of them. As the woman is more especially affected by child. bearing and rearing, she must be given special protection to ensure that her reproductive duties do not interfere too greatly with her opportunities to participate in the life and work of the community at large. These object 3 cannot be achieved unless there is an organization of production primarily for the benefit of consumer and worker, unless the conditions of employment are adapted to the needs of parents and especially of mothers, and unless dwellings, towns and community services generally are reshaped with the good of children as one of their main objectives.

A fourth prerequisite for effective genetic improve. ment is thelegalization, the universal dissemination, and the further development through scientific investigation, of ever more efficacious means of birth control, both negative and positive, that can be put into effect at all stages of the reproductive process-as by voluntary temporary or permanent sterilization, contraception, abortion (as a third line of defence), control of fertility and of the sexual cycle, artificial insemination, etc. Along with all this the develop- ment of social consciousness and responsibility in regard to the production of children is required, and this cannot be expected to be operative unless the above-mentioned economic and social conditions for its fulfilment are present, and unless the superstitious attitude towards sex and reproduction now prevalent has been replaced by a scientific and social attitude. This will result in its being regarded as an honour and a privilege, if not a duty, for a mother, married or unmarried, or for a couple, to have the best children possible, both in respect of their upbringing and of their genetic endowment, even where the latter would mean an artificial-though always voluntarycontrol over the process of parenthood.

Before people in general, or the State which is supposed to represent them, can be relied upon to adopt rational policies for the guidance of their reproduction, there will have to be, fifthly, a far wider spread of knowledgo of biological principles and of recognition of the truth that both environment and heredity constitute dominating and inescapable complementary factors in human wellbeing, but factors both of which are under the potential control of man and admit of unlimited but interdependent progress. Betterment of environmental conditions enhances the opportunities for genetic betterment in the ways above indicated. But it must also be understood that the effect of the bettered environment is not a direct one on the germ cells and that the Lamarclian doctrine is fallacious, according to which the children of parents who have had better opportunities for physical and mental development inherit these improvements biologically, and according to which, in consequence, the dominant classes and peoples would have become genetically superior to the underprivileged ones. The intrinsic (genetic) characteristies of any generation can be better than those of the preceding generation only as a result of some kind of selection, that is, by those persons of the preceding generation who had a better genetic equip. ment having produced more offspring, on the whole, than the rest, either through conscious choice, or as an automatic result of the way in which they lived. Under modern civilized conditions such selection is far less likely to be automatic than under primitive conditions, hence some kind of conscious guidance of selection is called for. 'T'o make this possible, however, the population must first appreciate the force of the above principles, and the social value which a wisely guided selection would have.

Sixthly, conscious selection requires, in addition, an agreed direction or directions for selection to take, and these directions cannot be social ones, that is, for the good of mankind at large, unless social motives predominate in society. This in turn implies its socialized organization. The most important genetic objectives, from a social point of view, are the improvement of those genetic eharacteristics which make $(a)$ for health, $(b)$ for the complex called intelligence, and (c) for those temperamental qualities which favour fellow-fecling and social behaviour rather than those (to-day most esteemed by many) which make for personal 'success', as success is usually understood at present. 
A more widespread understanding of biological principles will bring with it the realization that much more than tho prevention of genetic deterioration is to be sought for, and that the raising of the level of the average of the population nearly to that of the highest now existing in isolated individuals, in regard to physical wellbeing, intelligenco nnd temperamental qualities, is an achievement that would-so far as purely genetic considerations aro concerned-be physically possible within a comparatively small number of generations. Thus everyone might look upon 'genius', combined of course with stability, as his birthright. As the course of evolution shows, this would represent no final stago at all, but only an earnest of still further progress in the future.

The effectiveness of such progress, however, would demand incrcasingly extensive and intensive research in human genetics and in the numerous fields of investigation correlated therewith. This would involve the co-operation of specialists in various branches of medicine, psychology, chemistry and, not least, the socinl sciences, with the improvernent of the inner constitution of man himself as their central theme. The organization of the human body. is marvellously intricute, and the study of its genetics is beset with special difficulties which require the prosecution of research in this field to be on a much vaster scale, as well as more exact and analytical, than hitherto contemplated. This can, however, como about when men's minds are turned from war and hate and the struggle for the elementary means of subsistence to larger aims, pursued in common.

'Tho day when economic reconstruction will reach the stage where such human forces will be released is not yet., but it is the task of this generation to prepare for it, and all steps along the way will represent $a$ gain, not only for the possibilities of the ultimate genetic improvement of man, to a degreo seldom dreamed of hitherto, but at the same time, more directly, for human mastery over those more immediate evils which are so threatening our modern civilization.
F. A. F. Crew
G. P. Cinln
C.D. Darhington P. R. Davil)
J. B. S. Haldane G. Dahlbehg
P. C. Koller
IV. LANDAUER
S. C. Harland
Th. Dobzhanshy 13. I'rice
I. T. HogBex
R. A. Enkrsox
J. SCHU1,TZ
J. S. HUXLEY
C. Gordox
J. HAMmoND
II. J. MULLF:R
C. L. Huskiss
A.G.Steinber;
C. H. WAD- DINGTON

\section{CONTACTS OF RELIGION AND SCIENCE}

SIR RICHARD GREGORY, in choosing "Contacts $S$ of Religion and Science" ns the subject of his chairman's address prepared for the Division for the Social and International Relations of Science for the Dundeo meeting of the British Association, selected from the many topics of discussion open to him the one which, perhaps, most consistently holds the interest of thoso who are laymen in the double application of the term. He could have rendered no better service in both provinces of thought than he did by clarifying the issues, which in the popular mind aro so frequently, but as Sir Richard maintained, erroneously held to conflict.

At the very opening of his address Sir Richard mado his point of view clear when, after defining religion as "the reaction to an inner impulse as to what is conceived to be sacred and arouses awe or reverence", and science as "the accumulation of linowledge of the properties of natural objects-. animate and inanimate- in relation to man's needs and his understanding of them through the use of his intelligence", he went on to show that there can be no conflict between them when they aro conceived as joining in a higher unity, in which "all who are searching earnestly for truth, aro considered to be worshipping at the samo shrino". The dogmatisms of a few generations ago, both of men of science and theologians, are now giving way to a more liberal spirit. As ho said, "The study of science creates a feeling of infinite greatness in all who pursue it, and though it may lead to imperfect interpretation, its motive cannot be irreligious. . . . It is in the service of high ideals that science, without which we cannot live, and religion, without which most people see no meaning in life, can find a common field of action."

When Sir Richard had thus made clear his con. ception as a man of scienco of the relation between religion and science, ho proceeded in a brief historical survey to show what had been in fact the interactions of religion and science. Making special reference to the science of astronomy, he traced theso relations from their beginnings in primitive forms of society, through their development in the civilizations of IIesopotamia, Egypt, Indir, the cosmogonies of the Greeks, tho beginnings of modern scientific astronomical and physical knowledgo down to Darwinism and the development of the theory of evolution, "which placed man in a new relationship to the rest of living creatures".

In regard to evolutionary theory, or rather its mechanism, the struggle for existence, Sir Richard was at pains to point out the erroneous character of the view sometimes put forward that this is a striving after personal or national mastery at all costs-"a crude misconception repudiated alike by its founder, and by Huxley, its most powerful exponent, as contrary to the best ends of civilization". Further, man as "Nature's insurgent son", continually fighting against forces of evil which would destroy him, is yet able to survive by the use of his intelligence. "He may not know the reason for his existence, but he does know that thero is a law and order in thio natural world, and if he brealis them, the penalty is inevitable. Ifo has to oboy the lars of Nature in order to survive."

Iest the charge of materialism should be brough; against him for such doctrine, Sir Richard went on to show in effect that no brenk in the logical chain of argument, such as is sometimes imputed, is required to find a place for faith in such a view of Nature. For while "science is unable to provide any positive evidence for survival of personality after deaththat belief is a powerful ethical factor in human dovelopment. It is just as permissible, therefore, to assume that another world awaits habitation by an 